\title{
IS PRO BONO ALSO PRO LUCRUM? DOING WELL BY LETTING YOUR HUMAN CAPITAL DO GOOD
}

\author{
AMIT JAIN CHAURADIA \\ College of Business \\ University of Illinois, Urbana-Champaign \\ 1206 S. Sixth St. \\ Champaign, IL 61820 \\ DEEPAK SOMAYA \\ University of Illinois, Urbana-Champaign
}

\begin{abstract}
Many professionals derive value from engaging in pro bono work, which is also supported by a large and increasing number of employers. Using data from the legal industry, we find that firms' sustained commitment to pro bono and employee satisfaction with pro bono increases firm profit performance, and that the latter effect is moderated by key human capital strategy variables.
\end{abstract}

\section{INTRODUCTION}

Pro bono work by employees is widely prevalent and rapidly growing in the professions; including accounting, advertising, consulting and law, and even engineering and medicine (Cummings, 2004; Waller, 2010). Pro bono stands for pro bono publico, which in Latin means "for the public good," and refers to volunteer professional work performed as a public service. Thus, pro bono work is a component of corporate volunteerism, which has gained significant traction as an important and growing type of corporate social responsibility (CSR). For example, Grant (2012) reports that over $90 \%$ of Fortune 500 companies have employee volunteering programs and that these programs are one of the fastest growing areas of voluntary activity. Consistent with other aspects of CSR, company participation in volunteering has been characterized as a response to reputational or institutional pressures to be a good corporate citizen (Graves \& Waddock, 1994; Marquis, Glynn \& Davis, 2007), or reflecting the preferences and choices of organizational elites (Agle, Mitchell \& Sonnenfeld, 1999). When viewed from this perspective, however, human capital advantages are not significant drivers of volunteering programs; instead firms may need to induce employees to engage in volunteer activities (Grant, 2012; Peloza \& Hassay, 2006; Peloza, Hudson \& Hassay, 2009). By contrast, in this paper, we seek to explain the key role of human capital advantages in how pro bono work by employees impacts firm performance.

Human capital is widely understood to be a critical resource for firms, from which they derive competitive advantage and superior performance in various ways (Barney, 1991; Hitt, Bierman, Shimizu \& Kochhar, 2001; Lepak \& Snell, 1999; Nyberg, Moliterno, Hale Jr. \& Lepak, 2014; Ployhart \& Moliterno, 2011; Wright, McMahan \& McWilliams, 1994). Unlike other types of assets, however, the productive potential embedded in a company's employees can be neither owned by the firm nor compelled to perform. Inherently, the ability of firms to extract and capture value from human assets is constrained by the ability of talent to move, to bargain 
over rents, and to become dissatisfied or demotivated (Coff, 1997). A traditional solution to this dilemma emphasizes situations in which employees possess significant firm-specific skills, which limits both their mobility and bargaining power (Becker, 1964; Castanias \& Helfat, 1991; 2001; Hatch \& Dyer, 2004; Kor \& Leblebici, 2005; Wang, He \& Mahoney, 2009). Recent research, however, has urged the field to move beyond this focus on firm-specific human capital by understanding constraints on both the supply and demand sides to employee mobility (Campbell, Coff \& Kryscynski, 2012). We seek to examine whether a primary benefit and potential motive for firms to support employees' pro bono work is that it enables them to attract, retain and motivate employees who value these opportunities.

We develop a set of hypotheses linking the use of pro bono programs by professional service firms and their overall financial performance. Using a panel dataset of the largest U.S. law firms during the years 2004-2011, we find significant support for our proposed hypotheses. Specifically, we find that pro bono participation by law firms has no contemporaneous impact on performance; however law firms' sustained commitment to pro bono - which can be viewed as a proxy for the accumulation of organizational pro bono-related assets - is positively associated with firm performance. This association between pro bono "assets" and profitability is partially, but weakly, mediated by the satisfaction derived from pro bono by the firm's professional employees. Additionally, we find that the performance benefits derived from employee pro bono satisfaction increases with the degree of human capital leverage that firms employ. Thus, in highleverage firms, where less-expert junior professionals are likely to perform more "grunt work," receive less mentoring and feel demotivated, higher pro bono satisfaction disproportionately increases firm performance. Additionally, we find that pro bono satisfaction has a higher impact on performance in firms that have a larger proportion of highly inexperienced employees, who are also more likely to value pro bono opportunities.

\section{THEORY AND HYPOTHESES}

The theoretical framework we present in this paper advances two main theses. First, we theorize that pro bono work may provide non-pecuniary benefits to employees and thus lead to increased employee satisfaction. And second, sustained commitment to pro bono and employees' pro bono satisfaction may increase firm performance, and more so under conditions in which pro bono helps address fundamental dilemmas that firms may face in managing their human capital (Coff, 1997). We develop hypotheses within each of these sets of ideas, sequentially, below.

\section{Employee satisfaction with pro bono}

Greater opportunities to participate in pro bono work should lead employees of a firm, on average, to rate their satisfaction with pro bono to be higher. Consistent with similar arguments in the context of CSR more generally, a firm's support for pro bono work may be seen as a signal of the firm's own values and behavior, which may increase employees' satisfaction due to their identification with the firm and perceptions about fairness and justice in their own dealings with the firm (Aguilera, Rupp, Williams \& Ganapathi, 2007; Bhattacharya, Sen \& Korschun, 2008; Galbreath, 2010; Greening \& Turban, 2000; Turban \& Greening, 1997). Moreover, similar to other volunteer opportunities, pro bono work gives employees significant satisfaction because it is intrinsically worth doing, which is additionally reinforced by professional expectations (Cummings, 2004), and because it affords employees a higher degree of autonomy in choosing 
projects and in executing the work independently (Ryan \& Deci, 2001; Ryan, Huta \& Deci, 2008; Ryff \& Singer, 1998). Last but not least, because pro bono work is specifically within the professional domain of the participating employees, it provides them with opportunities to develop professional skills and knowledge that they might not otherwise have (Beckman \& Haunschild, 2002; Hatch \& Dyer, 2004; Hatch \& Mowery, 1998).

While the current level of pro bono work offered or allowed by the firm may matter to employees, a sustained historical commitment to pro bono - which we characterize as being embedded in firm-specific "pro bono assets" - may also have important impacts on the satisfaction employees derive from their pro bono work. Identifying and getting quality pro bono projects, setting up an efficient matchmaking system between employees and projects, and developing an infrastructure to support such a complex system are all capabilities that are built up gradually over time (Carpenter, 2010; Cummings, 2004), and as such exhibit time compression diseconomies that cannot be quickly overcome (Dierickx \& Cool, 1989). Firms that have gained experience with pro bono activities over time may become more efficient, in that there may be reduced transaction costs for employee-pro bono coordination (Cummings, 2004). Moreover, to the extent that pro bono work signals employer attributes and commitments to employees (e.g., Aguilera et al., 2007; Galbreath, 2010; Turban \& Greening, 1997), these signals could be perceived as being weaker if they are not sufficiently costly (Spence, 1973). Thus, the firm's longer run experience with pro bono can lead to an improved and more efficient pro bono capability, which may in turn enable firms to provide employees with superior pro bono experiences. Based on this logic, we predict:

H1. Besides its current levels of pro bono work, a firm's history of performing pro bono (pro bono assets) will be associated with higher employee satisfaction with pro bono.

\section{Pro bono assets, pro bono satisfaction, and firm performance}

We propose that higher levels of employee satisfaction with pro bono (on average, at the firm level), will be associated with superior firm performance. As discussed above, employees that are satisfied with the firms' pro bono activities are likely to have found both intrinsic value and meaning in their work as well as opportunities to develop their professional skills and knowledge through their pro bono assignments. These employees are in turn likely to be more engaged, motivated, and committed to the firm (Schmedemann, 2008; Traves, 2005). Extant research has shown that higher employee commitment leads to lower employee turnover, higher employee productivity, higher client satisfaction, and higher firm profit (Harter, Schmidt, \& Hayes, 2002). For example, lawyers often cite the causes of their dissatisfaction with their firm as related to the nature of the (perceived less meaningful) work assigned to them and the lack of opportunities to develop their skills (Rhode, 2003). Moreover, because employees derive nonpecuniary satisfaction and professional development benefits from pro bono opportunities, firms may be able set wages in the internal labor market that are lower than the competitive labor market, which in turn lowers their overall wage bill. We conclude that some firms may be able to provide superior pro bono experiences to employees at the same level of pro bono work and thus create higher pro bono satisfaction among employees at the same (opportunity) cost; therefore, these firms are likely to enjoy superior performance from the resulting human capital advantages of having committed employees. Accordingly, we predict: 
H2. Higher employee satisfaction with pro bono will be positively associated with a firm's profit performance.

Pro bono assets may also provide the firm with other benefits such as attracting employees to work for the firm and strengthening the firm's relationships with clients (Boutcher, 2011; Lardent, 2000). Pro bono assets signal a strong commitment to pro bono, and are thus likely to be viewed as being more credible by potential recruits, both at the entry-level as well as for experienced human capital who may be dissatisfied with pro bono opportunities at their current firms (Boutcher, 2011). In addition, pro bono assets may help firms to attract new customers and improve relationships with their existing customers (Lardent, 2000. We conclude that some of the impacts of pro bono assets on firm performance are likely due to its effects on the pro bono satisfaction of (current) employees, and we might therefore expect to see a mediating relationship between pro bono assets, employee pro bono satisfaction, and firm performance. However, some of the benefits firms derive from pro bono assets likely accrue from other sources such as advantages in the labor market and in customer relationships. Therefore, we expect partial but not full mediation of this relationship.

H3. Firms' pro bono assets will be positively associated with their profit performance.

H3A. Employees' satisfaction with their firm's pro bono will (partially) mediate the positive impact of the firm's pro bono assets on profit performance.

\section{Human capital advantages from pro bono work}

Prior research has found that firms are generally more profitable when they are more leveraged (Hitt et al., 2001; Kor \& Leblebici, 2005). However, high levels of leveraging also contribute to high levels of employee dissatisfaction. Employees are more likely to operate in large specialized teams doing repetitive work in highly leveraged firms, which leads to the perception that the work is less meaningful and that it lacks sufficient opportunities to develop professional skills. In prior work, it has been suggested that these deficiencies may be offset by the extrinsic motivation offered in a tournament model for promotion to the expert ranks in the firm (Galanter \& Palay, 1991). Put simply, employees are motivated by the significant benefits they assume they will receive if they successfully advance within the firm, which often implies that as partners they will share in the future profits of the firm. However, subsequent research has also highlighted the pitfalls of the tournament model, in particular that employees might become de-motivated if they discount the opportunities for advancement, either due to excessive leverage (Greenwood, Li, Prakash \& Deephouse, 2005) or the increasing use of intermediate less attractive promotion rungs such as non-equity partnerships (Galanter \& Henderson, 2008; Sherer $\&$ Lee, 2002). Therefore, the salience of employee pro bono satisfaction for addressing employee de-motivation and professional development needs is particularly high for firms with high leverage. Accordingly, we predict:

H4. The positive impact of employee satisfaction with pro bono on a firm's profit performance will be positively moderated by the extent of human capital leverage it employs, such that firms with higher (versus lower) leverage will exhibit a stronger positive relationship between employee pro bono satisfaction and firm performance. 
Motivating and developing novice inexperienced employees is a difficult challenge for firms, particularly in professional settings (Chauradia, 2014). One way to motivate and develop novice human capital is to offer them pro bono opportunities. Inexperienced employees desire pro bono opportunities more highly because the opportunity to develop their skills and handle client cases by themselves is more exceptional in their work lives. They begin to gain confidence because of their improved professional abilities that may be transferred to their everyday work (Cummings \& Rhodes, 2010; Galanter \& Palay, 1995). Therefore, firms gain an advantage from having novice employees "trained" through low-stakes pro bono experience, and motivated by the satisfaction they get from such work. As one partner at a large law firm noted, "paying clients pay an extraordinary amount of money for our services and often their cases are very high stakes so they want more senior, experienced lawyers taking the lead on their matters. On pro bono matters we are able to give younger lawyers or more inexperienced lawyers opportunities to stand up, lead matters, make strategic calls, do trials, do mediations, what have you at a much more junior level that gives them the skill sets they can use to transition into taking those kinds of roles on paying client matters." Accordingly, we propose:

\section{H5. The positive impact of employee satisfaction with pro bono on a firm's profit performance will be positively moderated by the extent of firms' inexperienced human capital.}

\section{DATA AND VARIABLES}

We use a firm-level panel data set from the legal industry to assess the impact of pro bono assets and employee pro bono satisfaction on profit performance. We chose the legal industry for studying the performance impacts of pro bono work because the legal industry has been a pioneer in this area, and reliable data are available regarding pro bono work and other firm attributes in this industry. In 2009, pro bono work performed by the 200 largest law firms in the U.S. amounted to approximately $\$ 1.65$ billion in lawyer time (at average billing rates). We combined data from a number of different datasets and surveys covering the largest U.S. law firms to construct our final sample, which consists of 140 firms observed longitudinally over eight years from 2004-2011. We employed fixed effects regression models with year dummies, and clustered the standard errors (by firm) to account for potential inconsistency in the standard error estimates. We also ran AR(1) models to account for potentially auto-correlated errors, and found largely similar results. To mitigate endogeneity, the main results regarding firm profits were estimated with independent variables that were lagged by one year.

\section{RESULTS}

We find strong support for Hypothesis 1 that controlling for firms' current pro bono work their pro bono assets built up over time (measured as a depreciated stock variable of prior pro bono work) positively impacts employee pro bono satisfaction $(\beta=0.001 ; p<0.05)$. We also find that employee pro bono satisfaction has a positive effect on profit performance (measured as profits per partner) $(\beta=78.74 ; p<0.01)$, supporting Hypothesis 2 . A one point increase in firms' employee pro bono satisfaction is associated, on average, with an increase in firms' profits per 
partner by $\$ 78,740$. We find strong support for Hypothesis 3 that firms' pro bono assets are also positively associated with profit performance $(\beta=0.001 ; \mathrm{p}<0.01)$. For Hypothesis $3 \mathrm{~A}$, we examine if the impact of pro bono assets on profit performance is partially mediated by employee pro bono satisfaction. We find that both pro bono assets and employee pro bono satisfaction are positively and significantly associated with performance, and firms' pro bono assets are positively and significantly associated with employee pro bono satisfaction. When we include both variables in a model, we see the impact of pro bono assets on profit performance remains positive and statistically significant, but the coefficient decreases by approximately $22 \%$ $(\beta=0.868 ; p<0.01)$; and the coefficient of employees' pro bono satisfaction also remains positive and statistically significant $(\beta=71.24$; $p<0.01)$. While these findings provide some support for the mediated relationship proposed in Hypothesis 3A, the extent of mediation observed is small. In Hypothesis 4, we predicted that firms with high leverage will benefit more from higher levels of employee pro bono satisfaction, and we find relatively weak support for this hypothesis $(\beta=59.81 ; \mathrm{p}<0.1)$. Finally, in Hypothesis 5 , we predicted that firms with higher levels of inexperienced human capital will benefit more from high levels of employee pro bono satisfaction. We find statistically significant support for this hypothesis $(\beta=852.6 ; p<0.05)$.

\section{DISCUSSION AND CONCLUSION}

In this paper, we seek to understand the relationships between firms' pro bono work and assets, employee pro bono satisfaction, and profit performance. In our empirical analysis, we find substantial support for our proposed relationships. First, we find that the firm's average level of pro bono work has an immediate impact on their employees' satisfaction (on average) with pro bono, likely because pro bono work provides opportunities for more meaningful work and professional development. Moreover, in addition, we find that law firms' sustained commitment to pro bono is positively associated with employees' pro bono satisfaction, which might occur because these pro bono assets enable firms to give employees a better pro bono experience. Second, we find that the firms' average levels of pro bono work have no contemporaneous impact on profit performance; however firms' pro bono assets and their employees' pro bono satisfaction are positively associated with profit performance. We find that the effects of pro bono assets on firm performance are partially mediated by better employee satisfaction with pro bono, which suggests that other mechanisms, such as client or stakeholder-related advantages, may also drive the pro bono assets-firm performance relationship.

Finally, we find support for important moderators of employee pro bono satisfaction's impacts on profit performance. In more highly leveraged firms, where employees are more likely to be de-motivated and lack significant on-the-job training and professional development opportunities, employee pro bono satisfaction has a stronger impact on firm profit performance. And, pro bono satisfaction also has a stronger positive impact on profitability in firms that have higher levels of inexperienced human capital, which is associated with firm-level strategies to build human capital internally. Our research shows that in addition to serving social needs by undertaking projects that help less fortunate clients, firms can also fulfill their larger organizational goals and enhance profit performance through pro bono work. Through our work we hope to stimulate a broader program of management research into the antecedents, organization and consequences of pro bono work.

\section{REFERENCES AVAILABLE FROM THE AUTHOR(S)}

